\title{
Pelatihan Pengolahan Ikan dan Pengemasan Produk Pertanian untuk Pengembangan Industri Hilir Desa Labuh Air Pandan
}

\author{
Reniati $^{1}$, Sumiyati*2, Muhammad Faisal Akbar ${ }^{3}$ \\ sumiyati.lec2019@gmail.com*2 \\ ${ }^{1,2,3}$ Fakultas Ekonomi, Universitas Bangka Belitung
}

\author{
Received: 13 Mei 2021 \\ Accepted: 5 Juli $2021 \quad$ Online Published: 31 Juli 2021 \\ DOI: 10.29408/ab.v2i1.3442 \\ URL: http://dx.doi.org/10.29408/ab.v2i1.3442
}

\begin{abstract}
Abstrak: Sektor pertanian, kehutanan dan perikanan di Bangka Belitung merupakan peyumbang terbesar kedua bagi produk domestik regional bruto (PDRB), sedangkan industri pengolahan merupakan sektor yang paling besar kontribusinya dalam PDRB. Namun Desa Labuh Air Pandan tidak tercatat sebagai penyumbang pendapatan asli daerah, padahal desa ini memiliki lahan pertanian terluas dibandingkan desa lain. Hal ini diakibatkan karena produk Desa Labuh Air Pandan belum dapat bersaing dengan produk lokal lainnya karena sejauh ini dikemas dalam bentuk konvesional. Selain itu, sebagai wilayah yang berbatasan langsung dengan selat Bangka, desa ini memiliki potensi hasil laut yang cukup banyak. Namun hasil laut yang diperoleh hanya dijual dalam bentuk komoditi mentah tanpa ada olahan lanjutan seperti produk jadi. Tujuan dilaksanakan kegiatan ini adalah untuk memberikan sosialisasi mengenai pengolahan ikan dan pengemasan produk untuk kelompok tani dan nelayan di Desa Labuhan Air Pandan. Metode pelaksanaan kegiatan pengabdian ini bersifat edukatif dan demontrasi dengan dilakukannya sosialisasi pembuatan kecap ikan dan sosialisasi pengemasan produk. Kegiatan ini berlangsung selama satu bulan di Desa Labuh Air Pandan. Evaluasi dilakukan dengan memberikan feedback berupa daftar pertanyaan terkait dengan tingkat pemahaman dan ketertarikan atas kegiatan ini. Berdasarkan hasil evaluasi tersebut, diketahui bahwa $80 \%$ peserta menyatakan memahami apa yang disampaikan dari sosialisasi pengolahan produk perikanan dan pengemasan produk pertanian
\end{abstract}

Kata Kunci: Edukatif; Industri Hilir; Pengemasan Produk; Pengolahan Ikan

\begin{abstract}
The agricultural, forestry and fishery sectors in Bangka Belitung are the second largest contributor to gross regional domestic product (GRDP). At the same time, the manufacturing industry is the sector with the most significant contribution to GRDP. However, Labuh Air Pandan Village is not recorded as a contributor to local revenue, even though this village has the most significant agricultural land compared to other villages because the village products have not competed with other local products. After all, so far, they have been packaged in conventional forms. In addition, as an area directly adjacent to the Bangka Strait, this village has quite a lot of potential for marine products. However, the marine products obtained are only sold in raw commodities without further processing, such as finished products. This activity aims to provide socialization regarding fish processing and product packaging for farmer and fisherman groups in Labuhan Air Pandan Village. The method of this service activity is educative and demonstration by conducting socialization of making fish sauce and socializing product packaging. This activity lasted for one month in Labuh Air Pandan Village. Evaluation is done by providing feedback in the form of a list of questions related to understanding and interest in this activity. Based on the results of the evaluation, it was found that $80 \%$ of participants stated that they understood what was conveyed from the socialization of fishery product processing and agricultural product packaging.
\end{abstract}

Keyword: Downstream Industry; Educative; Fish Processing; Product Packaging; 
Reniati, R., Sumiyati, S., \& Akbar, M. F., (2021). Pelatihan pengolahan ikan dan pengemasan produk pertanian untuk pengembangan industri hilir desa Labuhan Air Pandan. ABSYARA: Jurnal Pengabdian Pada Masyarakat, 2(1), 41-84. doi:10.29408/ab.v2i1.3442

\section{PENDAHULUAN}

Rencana Pembangunan Jangka Menengah Nasional (RPJMN) 2015-2019 mengamanatkan percepatan pembangunan pusat pertumbuhan ekonomi dengan menggali potensi dan keunggulan daerah terutama daerah di luar pulau Jawa. Industri hilirisasi merupakan salah satu upaya untuk meningkatkan nilai tambah dari bahan mentah.

Industri pertanian dibedakan menjadi dua jenis yakni industri pertanian hilir dan hulu. Industri pertanian hilir berperan untuk menciptakan output, nilai tambah dan impor. Sedangkan industri pertanian hulu berperan dalam penciptaan produk domestik bruto dan ekspor. Industri pertanian mampu menciptakan distribusi pendapatan masyarakat (Pratiwi \& Daryanto, 2017). Hal ini menunjukkan bahwa industri pertanian berarti mampu membuka lapangan kerja baru bagi masyarakat untuk meningkatkan pendapatan rumah tangga. Selain itu ada dua alasan menjadikan industri pertanian menjadi industri hilir seperti yang disebutkan oleh Rostow (1960) yakni pertama, sektor pertanian berperan besar dalam ketahanan pangan. Kedua, akan mampu mendorong terciptanya pasar yang makin besar dan dapat mendorong penyerapan tenaga kerja.

Pengembangan industri hilir agroindustri dengan penerapan paradigma big push mampu meningkatkan perekonomian suatu daerah (Farhan, dkk., 2020). Teori big push diperkenalkan oleh Rosenstein-Rodan yang menyebutkan bahwa salah satu cara untuk mengatasi pengangguran karena berlimpahnya tenaga kerja pertanian, maka harus ada industry yang melengkapi. Hal ini mengindikasikan bahwa komoditas pertanian harus disertai dengan industri pengolahannya.

Hasil penelitian yang dilakukan oleh Taluk, (2013); Howara, (2013) dan Bappenas, (2016) menyimpulkan bahwa Indonesia memiliki potensi ikan hasil tangkap yang sangat besar namun memiliki permasalahan yang dihadapi yakni potensi ikan wilayah pesisir belum dimaksimalkan, industri pengolahan ikan masih terbatas terutama sumber daya manusia dan infrastruktur, kapasitas produksi yang sangat rendah dan jaminan kualitas produk industri rumah tangga kecil menengah masih kurang.

Sektor pertanian, kehutanan dan perikanan di Bangka Belitung merupakan peyumbang terbesar kedua bagi produk domestik regional bruto (PDRB), sedangkan industri pengolahan merupakan sektor yang paling besar kontribusinya dalam PDRB. Selama tahun 2018, sektor industri pengolahan meningkat sebesar 0,26\% dari tahun 2017 (Tabel 1.1). Sementara itu, sektor pertanian, kehutanan dan perikanan meskipun mengalami penurunan dari tahun 2017 , rata-rata $18 \%$ berkontribusi pada PDRB.

Tabel 1.1 Produk Domestik Regional Bruto Harga Berlaku Menurut Lapangan Usaha 2018

\begin{tabular}{|c|c|c|c|c|c|}
\hline Industri & 2014 & 2015 & 2016 & 2017 & 2018 \\
\hline $\begin{array}{l}\text { Pertanian, Kehutanan, } \\
\text { Perikanan }\end{array}$ & 19.22 & 19.78 & 20.17 & 18.80 & 18.01 \\
\hline Pertambangan dan Penggalian & 13.52 & 12.68 & 11.90 & 11.71 & 10.59 \\
\hline Industri Pengolahan & 22.84 & 21.13 & 20.10 & 20.38 & 20.64 \\
\hline Pengadaan Listrik, gas & 0.08 & 0.08 & 0.10 & 0.11 & 0.12 \\
\hline Pengadaan Air & 0.02 & 0.02 & 0.02 & 0.02 & 0.02 \\
\hline
\end{tabular}


Reniati, R., Sumiyati, S., \& Akbar, M. F., (2021). Pelatihan pengolahan ikan dan pengemasan produk pertanian untuk pengembangan industri hilir desa Labuhan Air Pandan. ABSYARA: Jurnal Pengabdian Pada Masyarakat, 2(1), 41-84. doi:10.29408/ab.v2i1.3442

Konstruksi

$\begin{array}{lllll}8.36 & 8.63 & 8.85 & 9.12 & 9.73\end{array}$

Sumber: Badan Pusat Statistik Propinsi Bangka Belitung, 2018.

Industri hilir pertanian di Bangka Belitung dapat berkembang dengan baik. Hal ini dimungkinkan karena 69,10\% luas lahan masih dimanfaatkan sebagai lahan pertanian. Kabupaten Bangka merupakan kabupaten yang memiliki lahan yang digunakan untuk pertanian paling luas yakni sekitar 236.000 Ha dengan pemanfaatan lahan sebagai lahan sawah sebesar 3.463 Ha dan lahan bukan sawah sebesar 232.537 Ha (Tabel 1.2).

Pemanfaatan lahan untuk pertanian ini akan meningkatkan jumlah komoditas pertanian sebagai bahan mentah yang kemudian akan diolah menjadi barang jadi. Sektor pertanian dan industri pengolahan juga merupakan sektor penyumbang PDRB Kabupaten Bangka paling besar yakni 20,37\% dan 22,37\% pada tahun 2017. Kabupaten Bangka terdiri dari 8 (delapan) kecamatan yakni Sungailiat, Bakam, Pemali, Merawang, Puding Besar, Mendo Barat, Belinyu dan Riau Silip.

Tabel 1.2 Luas Lahan Menurut Jenis Penggunaan per Kabupaten/Kota (Ha), 2017

\begin{tabular}{lcccccc}
\hline \multicolumn{1}{c}{ Industri } & Bangka & Belitung & $\begin{array}{c}\text { Bangka } \\
\text { Barat }\end{array}$ & $\begin{array}{c}\text { Bangka } \\
\text { Tengah }\end{array}$ & $\begin{array}{c}\text { Bangka } \\
\text { Selatan }\end{array}$ & $\begin{array}{c}\text { Belitung } \\
\text { Timur }\end{array}$ \\
\hline Lahan Pertanian & 236.000 & 195.777 & 197.412 & 168.132 & 231.830 & 143.592 \\
Lahan sawah & 3.463 & 1.159 & 2.518 & 306 & 14.789 & 2.823 \\
Lahan bukan sawah & 232.537 & 194.618 & 194.894 & 167.826 & 217.041 & 140.769 \\
Lahan bukan Pertanian & 59.068 & 33.953 & 91.019 & 59.779 & 128.878 & 107.100 \\
\hline
\end{tabular}

Sumber: Provinsi Kepulauan Bangka Belitung Dalam Angka 2018.

Kecamatan Mendo Barat menjadi kecamatan dengan wilayah terluas yakni 683,7 Km2. Sedangkan luas lahan pertaniannya mencapai 17.155 Ha per tahun 2017 dan Desa Labuh Air Pandan merupakan desa dengan memiliki produksi padi ladang paling banyak (Tabel 1.3). Dengan lahan pertanian yang demikian luas, maka mata pencaharian sebagian besar penduduknya adalah petani. Meskipun lahan pertanian luas dan produksi padi mencapai 700 ton per tahun, namun Desa Labuh Air Pandan tidak tercatat sebagai penyumbang pendapatan asli daerah. Ini menunjukkan bahwa adanya pengelolaan produksi hasil pertanian belum maksimal. Data ini belum termasuk dengan produksi hasil pertanian lainnya seperti jagung, ubi cassava dan tanaman obat.

Tabel 1.3 Luas Panen(Ha) dan Produksi Padi Sawah dan Padi Ladang (Ton) Menurut Kelurahan/Desa di Kecamatan Mendo Barat Tahun 2017

\begin{tabular}{lllll}
\hline \multirow{2}{*}{ Kecamatan/Desa } & \multicolumn{2}{l}{ Padi Sawah } & \multicolumn{2}{l}{ Padi Ladang } \\
\cline { 2 - 5 } & $\begin{array}{l}\text { Luas } \\
\text { Panen }\end{array}$ & Produksi & $\begin{array}{l}\text { Luas } \\
\text { Panen }\end{array}$ & Produksi \\
\hline Kota Kapur & - & & 8 & 9,6 \\
Penagan & 10 & 34 & 15 & 15 \\
Rukam & - & & 7 & 6,3 \\
Air Buluh & - & & 5 & 4,5 \\
Kace & - & & 5 & 5,4
\end{tabular}


Reniati, R., Sumiyati, S., \& Akbar, M. F., (2021). Pelatihan pengolahan ikan dan pengemasan produk pertanian untuk pengembangan industri hilir desa Labuhan Air Pandan. ABSYARA: Jurnal Pengabdian Pada Masyarakat, 2(1), 41-84. doi:10.29408/ab.v2i1.3442

$\begin{array}{lllll}\text { Cengkong Abang } & - & & 6 & 4,5 \\ \text { Air Duren } & - & & 5 & 23 \\ \text { Petaling } & 13 & 51,2 & 12 & 73,8 \\ \text { Mendo } & 11 & 26 & 82 & 193,5 \\ \text { Paya Benua } & - & & 215 & 259 \\ \text { Kemuja } & - & & 7 & 7,2 \\ \text { Zed } & 17 & 75 & 8 & 82,6 \\ \text { Labuh Air Pandan } & - & & 120 & 278 \\ \text { Kace Timur } & - & & - & - \\ \text { Petaling Banjar } & - & & 10 & 47\end{array}$

Hasil pertanian Desa Labuh Air Pandan belum dapat bersaing dengan produk lokal lainnya karena sejauh ini dikemas dalam bentuk konvesional. Selain itu, sebagai wilayah yang berbatasan langsung dengan selat Bangka, Desa Labuh Air Pandan memiliki potensi hasil laut yang cukup banyak. Namun hasil laut yang diperoleh hanya dijual dalam bentuk komoditi mentah tanpa ada olahan lanjutan seperti produk jadi. Menurut Supriyati \& Suryani, 2016 pengembangan agroindustri di Indonesia masih memiliki peluang terbuka karena ketersediaan bahan baku yang cukup banyak.

Selain industri pengolahan, teknik pengemasan dan pemasaran juga sangat penting. Salah satu bauran pemasaran yang penting adalah produk dan pemasaran. Mengemas produk jadi yang menarik dan memasarkannya dengan memanfaatkan teknologi menjadi upaya untuk meningkatkan harga jual produk. Dengan meningkatkan nilai tambah produk, maka diharapkan mampu menyerap tenaga kerja rumah tangga.

Pentingnya dilakukan sosialisasi pengolahan ikan dan pengemasan produk bertujuan untuk meningkatkan nilai tambah dari sumber daya dan produk jadi. Diharapkan kegiatan ini dapat memberikan pemahaman dan memotivasi masyarakat dalam upaya menciptakan produk yang berkualitas.

\section{METODE PELAKSANAAN}

\section{Waktu dan Lokasi}

Kegiatan ini dilaksanakan pada bulan Agustus dan diselenggarakan di Desa Labuh Air Pandan Kecamatan Mendo Barat Kabupaten Bangka Propinsi Bangka Belitung. Desa ini berada kurang lebih $43 \mathrm{Km}$ dari pusat ibu kota propinsi. Subjek kegiatan ini adalah masyarakat Desa Labuh Air Pandan khususnya kelompok tani dan nelayan berjumlah 30 orang..

\section{Prosedur pelaksanaan}

Metode pelaksanaan dalam kegiatan ini berbentuk presentasi. Kegiatan ini dilaksanakan dalam bentuk presentasi berupa edukasi dengan mengajak masyarakat untuk mengelola sumber daya alam yang ada di desa. Edukasi dilakukan dengan dua program utama yakni sosialisasi pengelolahan produk perikanan dan sosialisasi pengemasan produk jadi. Ada dua program dirancang untuk mengatasi permasalahan terkait dengan produk hilirisasi pertanian dan perikanan diantaranya: 
1. Program sosialisasi produk perikanan

Program ini dilakukan dengan metode presentasi dimana masyarakat diedukasi mengenai pengolahan ikan hasil tangkap nelayan yang tidak memiliki nilai jual. Ikan tersebut adalah ikan kecil yang biasanya tidak dimanfaatkan oleh nelayan atau dibuang. Tujuan program ini adalah agar ikan tersebut dapat dijadikan produk yang bernilai ekonomis.

Tenaga ahli dalam kegiatan sosialisasi ini adalah Deny Saputra, S.Pi, M.Si. Beliau adalah dosen perikanan Universitas Bangka Belitung yang mengembangkan produk kecap ikan di Bangka Belitung.

2. Program sosialisasi pengemasan produk jadi

Pengemasan produk menjadi bagian penting dalam pemasaran produk dimana kemasan yang baik mampu menarik orang untuk membeli. Metode yang digunakan dalam program ini adalah metode presentasi dan demontrasi. Program pelatihan pengemasan produk dalam kegiatan ini diberikan oleh tenaga ahli dalam pengemasan produk. Adapun tenaga ahli tersebut Yulizar dan Donny dari Ahli Klinik Kemasan Provinsi Bangka Belitung. Peserta diajarkan untuk mengemas produk secara sederhana namun menarik

\section{HASIL DAN PEMBAHASAN}

HASIL

\section{A. Program Pelatihan Pengolahan Produk Perikanan}

Tujuan diadakannya kegiatan sosialisasi ini untuk dapat memberikan pengetahuan kepada masyarakat cara mengolah ikan-ikan kecil yang tidak bernilai jual untuk dapat dijadikan produk bernilai jual tinggi. Sosialisasi ini fokus terhadap pembuatan kecap ikan karena cara pengolahannya lebih mudah dan target pasar yang luas.

Kegiatan ini melibatkan masyarakat terutama nelayan sebagai peserta. Sosialisasi dilakukan bersifat edukasi yang memberikan informasi bagi masyarakat mengenai bahan utama dan cara pembuatan kecap ikan. Dalam kegiatan ini, pembuatan produk belum dilakukan secara langsung karena keterbatasan waktu. Adapun yang disampaikan kepada masyarakat diantaranya:

1. Ikan-ikan yang terbuang tersebut dibersihkan lalu dicincang halus dan dimasukkan ke dalam wadah.

2. Setelah itu diberikan garam dengan kadar $25 \%$ dari berat total ikan. Lalu ikan dan garam tersebut dimasukkan ke dalam wadah yang tertutup rapat dan dibiarkan selama kurang lebih 2 bulan.

3. Setelah 2 bulan, air (larutan kecap) dan daging ikan akan terpisah. Kecap ikan yang sudah jadi lalu dapat dikemas dalam botol dan ditambahkan label.

Selain cara pembuatan kecap ikan yang mudah, terget pasar dan konsumennya juga luas. Kecap ikan dapat dikonsumsi oleh banyak orang, baik bayi hingga lansia. Kecap ikan juga memiliki kandungan protein yang tinggi sebagai produk fermentasi. Hal ini menjadikan kecap ikan menjadi solusi ideal bagi para nelayan yang memiliki masalah di bidang pemanfaatan hasil tangkap. 


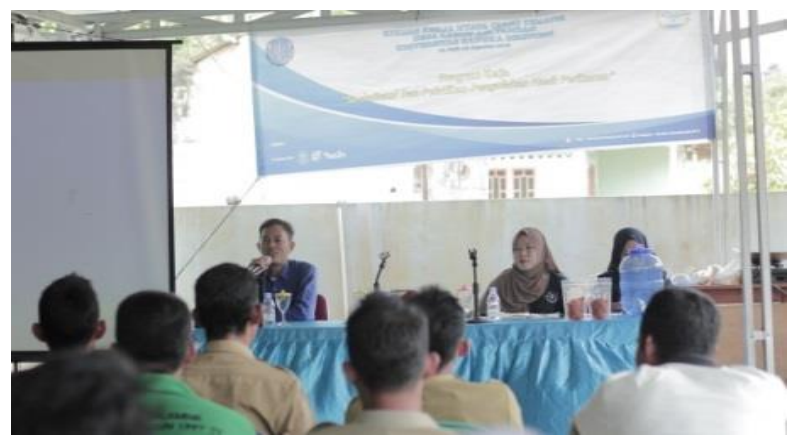

Gambar 1. Sosialisasi Pembuatan Kecap Ikan

\section{B. Program Pelatihan Pengemasan Produk Jadi}

Sosialisasi dan Pelatihan pengemasan produk pertanian merupakan salah satu program dari kegiatan pengabdian masyarakat ini. Program ini memberi gambaran serta pemahaman bagi pelaku usaha di desa labu air pandan tentang pentingnya pengemasan produk pertanian. Acara ini di ikuti oleh petani yang tergabung dalam Gabungan Kelompok Tani (Gapoktan) di desa labuh air pandan. Produk yang dipilih sebagai contoh untuk kegiatan ini adalah beras merah yang merupakan komoditas pertanian utama dari desa ini. Pengemasan beras merah dengan teknik vacuum sealer.

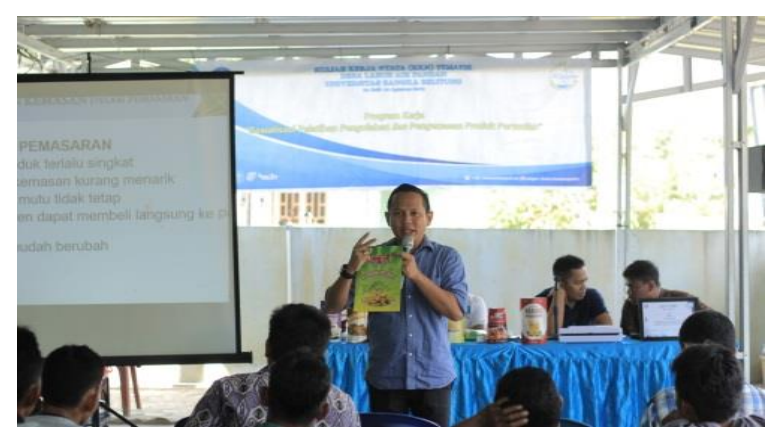

Gambar 2. Pelatihan Pengemasan Produk

\section{PEMBAHASAN}

Dengan adanya kegiatan ini memberikan pengetahuan bagi masyarakat sehingga masyarakat secara mandiri dapat mengembangkan produk pengolahan ikan yang potensial bagi peningkatan kemandirian ekonomi masyarakt desa. Kegiatan ini dapat dikembangkan menjadi produk jadi dengan memperhatikan beberapa hal sebagai berikut: 1) membentuk kelompok pengolahan ikan hasil tangkap secara terpadu di masyarakat pesisir; 2) melibatkan kelompok ibu rumah tangga untuk pengembangan usaha mikro; dan 3) meningkatkan daya saing volume produksi ikan hasil tangkap nelayan, hal ini sejalan dengan hasil temuan Marwan, dkk. (2013).

Selain peningkatan pengetahuan mengenai pengemasan produk, peserta pelatihan terlihat sangat aktif berdiskusi selama sosialisasi, hal ini menunjukkan bahwa kegiatan ini dapat dikatakan berhasil. Sejalan dengan yang dikemukakan oleh Zen, dkk., (2017) bahwa keaktifan peserta dalam berdiskusi merupakan salah satu indikator evaluasi kegiatan yang berhasil. Lebih lanjut lagi hasil kegiatan presentasi dan demontrasi pada kegiatan ini terlihat peserta kegiatan pengemasan produk mampu meningkatkan keterampilan dan kemampuan dalam mengemas produk agar dapat meningkatkan kualitas produk. Hal ini dapat dijadikan indikator keberhasilan kegiatan, sejalan dengan pendapat Anasrulloh \& Basiron (2017). Dengan 
Reniati, R., Sumiyati, S., \& Akbar, M. F., (2021). Pelatihan pengolahan ikan dan pengemasan produk pertanian untuk pengembangan industri hilir desa Labuhan Air Pandan. ABSYARA: Jurnal Pengabdian Pada Masyarakat, 2(1), 41-84. doi:10.29408/ab.v2i1.3442

melakukan evaluasi, program ini memberikan dampak signifikan bagi pengetahuan peserta kegiatan.

\section{SIMPULAN}

Program yang dirancang untuk melakukan sosiliasi kepada masyarakat untuk mengembangkan produk perikanan dan pengemasan produk pertanian. Kegiatan ini didukung oleh Pemerintah Desa Labuh Air Pandan dan disambut baik oleh masyarakat. Dengan adanya program-program ini, diharapkan masyarakat mampu memanfaatkan sumber daya yang tersedia di desa menjadi produk jadi yang bernilai tambah secara ekonomi dan memiliki kemampuan untuk mengemas produknya dengan lebih baik. Berdasarkan hasil evaluasi melalui lembar kuesioner yang diisi oleh peserta diketahui bahwa $80 \%$ peserta memahami penyampaian materi dalam kegiatan ini.

Program ini tidak dapat berjalan tanpa dukungan berbagai pihak terutama pemerintah daerah. Program ini juga harus dilakukan secara konsisten sehingga desa memiliki produk unggulan yang berdaya saing. Program selanjutnya dapat dilakukan bina desa dengan lebih intens sehingga tercipta UMKM yang dapat memproduksi produk-produk dalam program ini secara mandiri

\section{PERNYATAAN PENULIS}

Saya menyatakan bahwa artikel yang berjudul "Pelatihan Pengolahan Ikan dan Pengemasan Produk Pertanian Untuk Pengembangan Industri Hilir Desa Labuh Air Pandan” belum pernah dipublish pada jurnal yang lain.

\section{DAFTAR PUSTAKA}

Badan Pusat Statistik Bangka. (2018). Kabupaten Bangka dalam angka tahun 2018. Diambil dari https://bangkakab.bps.go.id/publication/2018/08/16/b02d0e8e59bfb96f88ec4676/kabu paten-bangka-dalam-angka-2018.html.

Badan Pusat Statistik Bangka. (2018). Kecamatan Mendo Barat dalam angka tahun 2018. Diambil https://bangkakab.bps.go.id/publication/2018/09/26/615a0e1fb589e84b194e0018/keca matan-mendo-barat-dalam-angka-2018.html.

Bappenas, R. (2016). Kajian Strategi Industrialisasi Perikanan Untuk Mendukung Pembangunan Ekonomi Wilayah. Industri, 1-22. Diambil dari https://www.bappenas.go.id/files/4115/0459/9921/Ringkasan-Kajian-StrategiIndustrialisasi-Perikanan-Untuk-Mendukung-Pembangunan-Ekonomi-Wilayah.pdf.

Farhan, W., Hartono, I. W., \& Meganingrum, Y. (2020). Penerapan teori Big Push dalam pengembangan ekonomi lokal untuk mengatasi kemiskinan Jember. MATRAPOLIS: Jurnal Perencanaan Wilayah dan Kota, 1(1), 15-30.

Howara, D. (2013). Strategi pengembangan pengolahan hasil perikanan. Jurnal Agroland, 17(3), 75-81. 
Marwati, U. M., Wiryawan, B., \& Lubis, E. (2013). Kajian strategi pengembangan industri pengolahan ikan di Kota Palopo Provinsi Sulawesi Selatan. Jurnal Teknologi Perikanan dan Kelautan, 4(2), 197-209.

Anasrulloh, M., \& Basiron, B. (2017). Pelatihan pembuatan kemasan (packaging) untuk meningkatkan pemasaran produk olahan Kue Kacang Emping Melinjo. J-ADIMAS (Jurnal Pengabdian Kepada Masyarakat), 5(1).

Pratiwi, N. A., Harianto, H., \& Daryanto, A. (2017). Peran agroindustri hulu dan hilir dalam perekonomian dan distribusi pendapatan di Indonesia. Jurnal Manajemen \& Agribisnis, 14(2), 127-127. https://doi.org/10.17358/JMA.14.2.127

Rostow, W.W. 1960. The stages of economic growth: a non-communist manifesto. Cambridge University Press, Cambridge.

Supriyati, N., \& Suryani, E. (2016). Peranan, peluang dan kendala pengembangan agroindustri di Indonesia. Forum Penelitian Agro Ekonomi, 24(2), 92-106. https://doi.org/10.21082/fae.v24n2.2006.92-106.

Taluk, A., (2013). Pengembangan strategi industri pengolahan ikan PT . Palu Jaya Utama Kecamatan Palu Utara Kota Palu Sulawesi Tengah. Agrotekbis, 1(2) : 159-165.

Zen, Z. H., Satriardi, S., Dermawan, D., Anggraini, D. A., \& Yul, F. A. (2017). Pelatihan desain kemasan produk UMKM di Kecamatan Tambang, Kabupaten Kampar. Jurnal Pengabdian Untukmu Negeri, 1(2), 12-15. 